\title{
Causes of Low-Skilled Workers' Performance in Construction Projects
}

\author{
Alhaji Ali Zannah ${ }^{1}$, Aryani Ahmad Latiffi ${ }^{2}$, Abdulazeez Umar Raji ${ }^{3}$, Abdullahi Abba Waziri ${ }^{4}$, \\ Usman Mohammed ${ }^{4}$
}

${ }^{1}$ Mai Idris Alooma Polytechnic

P. M. B. 1020, Geidam, Yobe State, Nigeria

${ }^{2}$ Universiti Tun Hussein Onn Malaysia

101 Parit Raja, Batu Pahat, Johor, 86400, Malaysia

${ }^{3}$ Modibbo Adama University of Technology Yola

P. M. B. 2076, Yola Adamawa State, Nigeria

${ }^{4}$ Federal Polytechnic Mubi

P. M. B. 35, Mubi, Adamawa State, Nigeria

DOI: $10.22178 /$ pos.23-7

LCC Subject Category: HM786-806

Received 25.05.2017

Accepted 21.06.2017

Published online 24.06.2017

Corresponding Author:

Alhaji Ali Zannah,

Zannah2200@gmail.com

(c) 2017 The Authors. This article

is licensed under a Creative

Commons Attribution 4.0

License @) (1)

\begin{abstract}
Skilled workers' performance is one of the crucial aspects of labour productivity that requires proper attention for effective projects delivery in the construction industry. The level of skilled workers' low performance has been seen to be a major factor which contributes toward inefficient construction projects productivity. Therefore, the objective of this research is to identify the causes of low-skilled workers' performance in construction projects in the Nigeria. The objective was achieved through a structured quantitative method of questionnaire distributed to 150 respondents that comprise of active stakeholders in the Nigerian construction industry. 111 responses representing $74 \%$ were retrieved. The data were analysed using descriptive statistics and analysis of variance (ANOVA). The finding shows that; low wages of skilled, lack of sufficient skill acquisition centres and lack of incentive schemes for skilled workers were the most significant causes of low-skilled workers' performance in the Nigerian construction industry. The homogenous analysis indicates that there are significant differences in perception of respondents on few variables whereas majority of respondents have similarities in most of the variables. The research findings indicate the need for stakeholders in the Nigerian construction industry to provide incentives and motivate skilled workers, provide training and retraining, conducive working condition, supply of quality materials and equipment, and proper site management in order improve low-skilled workers' performance in Nigerian construction industry towards optimal performance.
\end{abstract}

Keywords: project performance; skilled workers; construction industry.

\section{Introduction}

Construction industry in many developing countries are greatly concerned with low level of skilled workers' productivity due to economic, social, physical and psychological related factors influencing the performance of the skilled workers [47]. Low productivity of skilled workers' is one of the most serious task facing the construc- tion industry especially in developing countries such as Malaysia, Indonesia, Singapore, Hong Kong, and other states in South east Asia [40]. In today's global economic, skilled workers' productivity is becoming more intense than ever due to the low level of quality performances of the skilled workers in the construction industries in most developing countries [24]. M. Arshad and 
Ab Malik [14] assert that, productivity improvement can be achieved when construction workers with high skills and knowledge, together with sound physical and mental health perform tasks with efficiency and effectiveness. In most countries, the cost of operatives comprises $30 \%$ to $50 \%$ of the overall projects' cost, and thus, it is regarded as a true reflection of the efficiency of the operation [41].

Nigeria's commitment to improving the living standard of its citizens has led to the introduction of a long-term economic programme tagged ' $\mathrm{Ni}$ geria vision 20:2020'. The vision consists of a set of objectives and programmes designed to launch the nation into the league of the twenty most developed economies of the world by the year 2020 [5]. Y. Almutairi [11] stressed that, a large number of skilled workers' low performance, especially in the construction industry has been identified by several studies as critical factor for the vision 20:2020 to be achieved. Therefore, the issue of low-skilled workers' performance in construction projects is important in order to establish a substantial foundation to improve it so as to achieve efficiency of work and higher productivity.

Skilled Workers in the Construction Industry. According to T. Griggs [30], the structure of labour force in the construction industry are categorised into skilled and unskilled workers. The labour force under the skilled workers are of varying abilities ranging from apprentices to trades foremen or supervisors [43]. The apprentice can be described a beginner who is willing and interested in learning a certain trade in the construction industry. The three possible avenues for training skilled workers are; schools, vocational training centres, workshops and on sites [34]. According to [17], skilled worker is a segment of the work force with a high skill level that creates significant economic value through the work performed. Skilled worker is generally characterised by high experience and expertise level and involves complicated tasks that require specific skill sets, education, training and experience, and may involve abstract thinking. S. Sweet and P. Meiksins [67] asset that, a skilled worker requires some form of professionalism and training which does not require a college degree or the like. Common skilled workers include electrician, plumber, painter, carpenter and mason, bar bender, tiller, plant operator, welder, mechanics, and steel fixer [68].
Categories of Skilled Workers in the Nigerian Construction Industry. According to O. Ogochukwu [52], the Industrial Training Fund (ITF) in Nigeria enumerated the followings as recognised skilled workers in the construction industry, namely; masons, steel fixers, electricians, carpenters, plumbers and welders. L. Uchitelle [68] asserts that, common skilled workers include electricians, plumbers, painters, carpenters and bricklayers, bar benders, tile fixers, plant operators, welders, mechanics, and steel fixers. K. Offei-Nyako [51] stressed that, skilled workers vary from mason, carpenter, tile worker, steel worker, painter, electrician and plumber.

The study of 0 . Ameh and B. Shokumbi [12] viewed that, skilled workers in the construction industry include; iron bender, carpenter, bricklayer, painter, electrician, welding worker, plumber and tiler. However, P. Adewale [5] listed categories of skilled workers which include; carpenter, bricklayer, painter, iron bender and plumber. B. Oseghale [59] assets that, frequent used skilled workers in the construction industry include; carpenters, bricklayers, bar bender, plumbers and painters where their services are required most in construction projects. V. Sherekar and M. Tatikonda [65] identified the major categories of skilled workers in the construction industry as; mason, painter, steel fitter and plasterer. Therefore, from the various categories of skilled workers mentioned by various researchers, there are significant similarities among the researchers on the different trade specialisations of skilled workers in the construction industry.

\section{Criteria for Selection of Skilled Workers in Con-} struction Projects. According to Y. Ling and F. Tan [44], it is important for contractors to be familiar with some criteria in selection of efficient skilled worker that can leads to efficient productivity of any construction projects. J. Sheebe [64] opined that, the pride and satisfaction of every skilled worker carrying task by building structures that are useful to people are more than enough to make up for the physical and mental demands that come with the job. However, before venturing in any of the construction skilled career, one must possess certain qualities and skills, which are requisites for the chosen job. Such skills and qualities can be acquired through education, vocational trainings and experience. 
Therefore, the criteria for selection of skilled workers in construction projects comprises of the followings:

\section{Physical strength and stamina}

2. Manual dexterity and coordination

3. Knowledge and analytical skills

4. In-depth knowledge in handling tools and equipment

\section{Causes of low-Skilled Workers' Performance in} Construction Projects. P. Zou [73] stressed that, causes of low-skilled workers' performance mainly arise in large construction projects due to seven reasons such as unfair wages, lack of motivation and incentives, lack of training and retraining, inclement weather condition, design changes, use of low quality tools and equipment and delay in deliverance of materials to sites. I. Odesola [48] however, identified causes of lowskilled workers' performance such as, shortage of skilled workers on sites, poor site management, lack of safety and health services, inefficient plants and equipment and unnecessary overcrowding of skilled workers. A. Kazaz [41] consider factors of low-skilled workers' performance under four categories, namely; organisational factors, economic factors, physical factors and socio-psychological factors, based on the theory of motivation. B. Hickson and L. Ellis [32] identified seven prevalent issues of low-skilled workers' performance such as; delay in deliverance of materials and equipment, shortage of plants and equipment, incompetent management, excessive rework, lack of incentive schemes, lack of motivation and improper schedule of work.

I. Odesola [49] classified factors of low-skilled workers' performance into five broad groups, namely; management-related factors, labourrelated factors, environmental-related factors, project-related factors and natural-related factors. O. Ogochukwu [52], opined that, poor supervision, shortage of skilled workers, delay in supply of materials to site, high rate of accidents on sites and conflicts among skilled workers, are factors leading to low performance of skilled workers. A. Jarkas and M. Radosavljevic [38] identified nine most significant factors causing low-skilled workers' performance, such as; delay in payment of wages, too many rework, lack of financial and non-financial incentive schemes, extent of change orders during project execution, incompetent supervision, delay in responding to requests for information, overcrowding of skilled workers, unrealistic scheduling of programme of works and shortage of materials and equipment on sites.

Low wages of skilled workers. Low wages and salaries have been a great factor leading to low performance and productivity of skilled workers in the Nigerian construction industry which as a result, affect their motivation toward willingness to carry out their tasks, this in turn reduces projects productivity and quality of work [8]. According to J. Salisu [62], contractors do not pay fair wages to skilled workers, and this can be traced to the government scarce of resources in the country and harsh economic situations due to poor leadership style. For this reason, contractors tend to give unfair wages and that adversely demotivate skilled workers therefore instigate them to migrate to other organisation with lucrative wages.

Delay in payment of skilled workers' wages. B. Hickson and L. Ellis [32] are of the view that, payment delay normally occurs as a result of cash flow originating from the client, contractor and by poor planning and management of fund on projects. Regardless of the source of the payment delay, skilled workers tend to create confusion and conflict, which subsequently hampers the work progress. According to P. Ghoddousi [29], lack of timely payments to contractors has a negative impact on the skilled workers on site. It has been a clear fact that, if skilled workers do not receive their wages on time, they feel unsatisfied and this may cause lack of loyalty to their work, hence productivity decreases. Delay of payment of wages may occur as a consequence of inadequate financial resources of contractors usually as a result of delay of funds from the clients [27].

Lack of standard salary scale for skilled workers'. In Nigeria, there is no hard and fast rule concerning to the minimum, wages for the construction skilled workers as different wages are being paid in different sites across the country. This normally prompts the skilled workers to migrate to where they will be better paid [7]. In addition, B. Garcés-Mascareñas [28] opined that, construction skilled workers always tend to migrate to other construction organisations where skilled workers' wages are standardized and fixed with good outcome. On the other hand, shortage of skilled workers in construction organisations become apparent where the salary is not fixed rather it varies from individual level of performance. 
Lack of incentive scheme programmes for skilled workers. O. Aina and D. Adesanya [7] assert that, lack of incentive scheme one of factors leading to skilled workers' demotivation in organization, and for this, organizations must look to offer incentives such as bonuses to skilled workers to bring their good environmental practice into the workplace. D. Abdulsalam [2] emphasised that, incentive schemes to promote environmental responsibility must provide a financial incentive to encourage more flexible working practices and a better work life balance to skilled workers. H. Bernardin [16] also listed factors such a skilled workers' lack of financial incentives have been observed to be a non-implemented motivational factor in most organisations, thereby, gives rise to low performance of the skilled workers.

Lack of free residential accommodations for skilled workers. According to A. Bilau [18], accommodation is often associated with the importation of an external workforce into an area. This can occur in a situation where the local skills base is inadequate, because the skilled workers are simply not available due to the remote location of the worksite and the particular skill requirements can only be satisfied by migrant skilled workers due to the nature of the work. According to O. Adedokun [4], provision of skilled workers' free housing may relate to a temporary phase of a project such as, a construction camp, and may be more permanent such as, a factory dormitory camp. Therefore, lack of free residential accommodations for skilled workers in an organization make less motivation for them especially for migrant skilled workers whom cannot afford to pay for their accommodation.

Lack of free food vouchers for skilled workers. According to A.Attar [15], free meal for skilled workers at workplace leads to their high morale both in terms of performance and productivity. Free meals provided in construction organisation's canteen where meals are provided for general staff including skilled workers, and a ticket is used to get such meals for free. P. Kuroshi [42] opined that, meals are provided on a reasonable scale in such a way that, all skilled workers can get free foods either on the construction site premises or elsewhere. It has been found out that, most construction organizations do not provide free meal vouchers for skilled workers because they deem as not within the project budget, thereby, issuing free meal vouchers for skilled workers will affect their project cost budget and this can result to poor financing of the project.

Lack of free transportations for skilled workers. K. Adamu [3] indicated that, a number of concerns have been raised over construction industry in Nigeria, especially the large organizations for lack of provision of free transportation system to skilled workers. A. Funso [27] stressed that, little focus has been given in the construction industry on motivating skilled workers in order to move the industry in the right direction, especially in terms conveying skilled workers to construction sites before and after working hours. It has been noted by O. Akinsiku and A. Akinsulire [9] that, most skilled workers use their resource to transport themselves to the construction site, and this results to many factors such as delay in commencement no work, delay in completion of work within time frame, waiting for skilled workers on sites, making schedule of programme of work distorted.

Lack of free medical facilities for skilled workers. O. Aina [7] noted that, most construction companies in Nigeria do not take as a duty bound to provide free medical facilities to skilled workers whereas, construction sites are known to be liable to accidents, hazards and all sort of risks. According to R. Parida [60], lack of free medical facilities such as first aid, to treat skilled workers on emergency situations will probably lead to their poor performance and productivity in delivering their tasks. H. Chandra [20] noted that, in a critical and severe, lack of free medical facilities for skilled workers may even result to death and this will give rise to sudden migration of skilled workers to other organisations issuing free and effective medical facilities.

Lack of opportunity to observe public holidays for skilled workers. Most skilled workers' in the construction industry are working in full-time, and sometimes the working hours are more than forty hours in a week. Scheduling of extended work days or weeks exceeding a standard eighthour work day or 40 hours work week lowers work output and efficiency through physical fatigue and poor mental attitude [45]. The lack of opportunities to observe public holidays, may be addressed as a morale factor since the skilled workers are away from their families and working instead of enjoying the holidays, in such case, there is usually low performance and productivity during construction work [36]. 
Lack of gifts during festive periods for skilled workers. According to J. Salisu [62], gift consists of goods and vouchers during festive periods are only issued to top managers in construction organizations, whereby skilled workers do not enjoy such gifts. The result of this may give perception to skilled workers that, they are not given full recognition, less esteem and their work is not appreciable by the organization. R. Cox [22] assert that, high expectations from skilled workers in an organization tend to be high whenever such festive periods approach, where they can easily add to what they earn and enjoy the festival with their families and relatives whenever they are rewarded such gifts.

Lack of sufficient skill acquisition centres for skilled workers. D. Ikediashi [37] revealed that, despite the invaluable contribution of construction companies in Nigeria economy, a large number of skilled workers still lack sufficient training centres to improve their skills in order to meet the requirement toward current trend. J. Wong [70] added that, construction industry all over the world have been adapting to the sporadic change in technologies with skills acquisition programme to meet the demand due to this changes, but most construction companies in $\mathrm{Ni}-$ geria are yet to adopt this trends. These development and technological advancement has great constraints and influence on the skilled workers.

Ineffective vocational training programmes for skilled workers. N. Okafor [54] observes that, there is total decline in the quality of training facilities at all levels of Nigerian vocational education system. Many technical and vocational training institutions do not have the necessary facilities for effective teaching and learning. L. Odia and S. Omofonmwan [50] identify lack of necessary facilities such as tools and insufficient training workshops as one of the factors which hinders in-depth practical instructions to train skilled workers effectively. C. Oni [58] advocates the need for proper funding of technical and vocational education due to acute shortage of suitable, trained and qualified vocational teachers is another identified constraint facing the Technical and Vocational Education in Nigeria.

Lack of issuance of training certificates for skilled workers. In Nigeria, the lack of issuance of training certificate which can serve as an evidence that a skilled worker is qualified in certain trade has been a major concern due to the fact that, large organizations use such certificate to employ skilled workers [58]. N. Aniekwu and C. Ozochi [13] assert that, forum provided an opportunity for stakeholders in the vocational education and training skilled workers in Nigeria to brainstorm on developing appropriate methodologies for assessing, monitoring and evaluating skills in technical and vocational qualifications and issuance of certificates of proof for skilled workers' qualifications. B. Ogwu [53] added that, training of skilled workers can be achieved through a comprehensive issuance of certificates which will serve as a clear proof of their qualification obtained from the vocational and technical training.

Vulnerability to safety and health care services on site. An accident that causes an injured skilled worker to be hospitalised results in a work decrease for which the injured skilled worker performed. Minor injuries resulting from nails and steel wires can stop work and, thus, decrease productivity [56]. M. Hyder [35] asserts that, insufficient lighting leads to decrease in productivity, because sufficient lighting is required so that construction works will be carried out efficiently. R. Parida [60] suggest that, special attention should be paid to risks such as accidents, and other detrimental consequences of increased traffic generated by the project such as; dust, noise, and pollution. P. Hughes and E. Ferrett [33] revealed that, requirements on fire safety are common and are likely to apply as construction facilities of any type. These include; provision on fire extinguishers, fire alarms, number and size of staircases and emergency exits, restrictions on the use of certain building materials.

Unfavourable weather condition. According to V. Venugopal [69], the building industry in SubSahara Africa has unique characteristics and construction work is labour intensive as it is largely in-situ whereby skilled workers are exposed to extremes of hot and wet weather conditions which leads to poor performance. W. Schwarzkopf [63] identified four factors in hot environment that cause low-skilled workers performance and increase unbearable stress, namely; humidity, air movement, high temperature and heat radiation. According to V. Rojas and B. Kleiner [61], Nigeria being in the equatorial region, experiences wet and dry conditions. The rains are heavy but in many cases last for a short time. The afternoons are generally hot usually at a maximum temperature of about $30^{\circ}$ to $35^{\circ} \mathrm{C}$. Therefore, heating, air-conditioning and ventilation should be appropriate for the climatic condi- 
tions and provide skilled workers with a comfortable and healthy environment to rest and spend their spare time.

Outdated machines for operation on site. A. Aibinu and G. Jagboro [6] asset that, outdated machines for operation such as such vibrators, water pumps, concrete mixers, flooring machines and powered machinery which are old and obsolete and outdated cannot be effective for heavy construction projects, and apparently result to low performance of skilled workers' productivity. Machine skilled operators according to H. Alinaitwe [10], work in nearly all weather conditions and operating machines often work for less hours because when allow to operate for several hours, it will easily result to knock down due to its obsolete nature. K. Kamar [39] opined that, vast majority of skilled operators find in difficult to smoothly manoeuvre machines for the operation and that leads to their project delay and extension which skilled workers feel discourage in terms of their performances

Shortage of plants and equipment on site. Shortage of plants and equipment such as; scaffolds, cranes, can easily break and give errors during construction activities [15]. In such case, construction progress suffers great set back and cost, time and quality will not be successful achieved. A. Enshassi [26] viewed that, skilled workers always need sufficient plants and equipment to motivate them complete their work successfully and within targeted time. This indicates that, where there are shortage of plants and equipment on the site, skilled workers find it difficult to carry out their task smoothly thereby this leads less productivity. Shortage of plants and equipment on site will also results in their lack of interest and morale toward carrying out their required tasks [23].

Plants malfunction and maintenance on site. Plants malfunction such as cranes, heavy duty trucks, bulldozers and caterpillars in relation to their breakdowns has been one of the factors militating the performance of skilled workers in charge of plants operations [27]. According to P. Sinha [66], lack of plant function is due to poor maintenance and lack of regular service which result to various plants not in the best condition as they lack spares for replacements. There is a need for good garages and mechanical workshops to take care of the repairs and maintenance and for contractors to understand that there is optimal age for replacing such tools and equipment.
Excessive rework by skilled workers due to design errors. During project execution, rework arises mainly as a result of poor supervision, errors, omissions, change orders, poor coordination and ineffective communication, thus, having to redo the work again can be greatly frustrating, discouraging and dissatisfying to the skilled workers [26]. Furthermore, revisions or substantial alterations according [10], can lead to major rework on sites, especially at an advance stage of the construction process, which creates an atmosphere of frustration, dissatisfaction and demotivation to the skilled workers. For skilled workers to perform effectively, O. Olubodun [57] opined that, skilled workers must clearly understand what requires to be done in process of the construction in order to avoid unnecessary errors and exaggerations of work.

Overcrowding of skilled workers' during project execution. According to A. Jarkas and M. Radosavljevic [38], overcrowding of skilled workers also occurs when operations take place within physically limited space with other contractors, resulting in congestion of personnel, inability to use or locate tools conveniently, increased loss of tools, additional safety hazards, increase visitors, and prevention of crew size optimum. This is caused when work planners hire too many skilled workers for the estimated work scope and duration. K. Chandrasekar [21] opined that, in a situation when skilled workers in certain area are scarce and hard to get, work planners may overcompensate for potential absenteeism and turnover, which creates overcrowding. This overcrowding of skilled workers in a construction site will always result in decrease of work productivity.

Change of orders of during project executions. Extent of change orders during project execution has an adverse impact on the performance of skilled workers in construction [46]. Change order is a written instruction from the employer, architect engineer or any authorised party to depart from the previously agreed upon plans and specifications for the construction. Such order is most often related to design changes as a result of incomplete or unclear plans and specification and omission of important details [38]. This change of orders during construction work have negative effect on skilled workers through unwilling to perform better.

Delay in supply of materials and equipment to site. B. Olateju [55] stressed that, delays in the deliv- 
ery of materials and equipment, poor welfare facilities and faulty plants and equipment on sites is definitely affecting skilled workers output in a negative manner. According to V. Yerramreddy [71], materials and equipment delay consume a lot of the contractors' time, cost and quality, that makes the work relatively behind schedule. The main cost incurred due to delay of materials and equipment is for the idle time that skilled workers have to wait for the supply of materials and equipment before they continue with their tasks. But since a good number are employed on short contracts and casual terms, it implies that when there are no materials, they can also afford to wait without transmitting extra costs to the contractor. In addition, delay in supply of materials and equipment raises the skilled workers' demotivation level and subsequently decreases the efficiency of the operation on sites [26].

Conflicts among skilled workers on site. According to J. Brockman [19], most construction sites in Nigeria where large construction projects are going on, conflicts among skilled workers such as disagreements, misunderstandings and sometime fighting are inevitable usually due to contractors favouring some. M. Hershcovis and J. Barling [31] opined that, among the primary triggers for conflicts among skilled workers are; perceived safety issues, rework, construction rescheduling, change in specification, poor working condition, improper communication, poor coordination of skilled trades and continuous blaming. H. Doloi [25] stressed that, impact of the presence of skilled workers with different lifestyles or cultural backgrounds on the host community needs to be assessed and managed, in particular issues such as religious or other cultural proscriptions, local traditions and community structure. L. Zhang and X. Huo [72] assert that, it is not possible to eliminate conflict from a workplace, but establishing clear guidelines for work responsibilities, promotion practices, and scheduling issues can go a long way toward creating a harmonious environment

\section{Methodology}

This paper presents the findings from a research conducted on causes of low-skilled workers' performance in Nigerian construction industry. The scope of the research covers the key stakeholders in the construction industry such as; project managers; project engineers; site engineers; and site supervisors. A research question was asked in order to guide the investigation: What are the existing common factors that lead to skilled workers' low performance in the Nigerian construction industry? However, this section deals with the research methodology adopted in conducting this research. The methodology employed in this study is quantitative method as discussed below.

The target population comprised of key stakeholders in the construction industry in Borno state Nigeria. Convenience sampling technique was used in the administration of questionnaire for this study. After taking into consideration the large number of potential respondents in the sample size along with the information required to achieve the research objectives the research instrument decided on was a questionnaire. On the other hand, after taking into consideration the different methods available to administer a questionnaire, the online-survey using survey monkey was deemed as the most suitable research instrument for the current study. This method was decided upon because it would enable the collection of large quantities of data from a sizable population sample with relative ease and therefore aid the administration process.

Due to the quantitative nature of the current research, Statistical Package for Social Sciences (SPSS, version 22.0) was used to analyse the data obtained from the questionnaires. After assessment of the questionnaires it was found that the total number of questionnaires administered was 150 respondents. However, on closer inspection this number was reduced to an actual usable sample size of 111 respondents or $74 \%$ of the total questionnaire administered. This was due to 19 questionnaires that were incorrectly completed and as a result deemed ineligible for use. In addition, 20 questionnaires were not retrieved up to the time of analysis, as it was taking a longer time and difficulty in locating the respondents. Likert Scale scoring of 1-5 was used for the questionnaire administered.

\section{Results and Discussion}

As shown in Table 1 below, 51 respondents representing $46 \%$ were project managers whilst 20 respondents representing $18 \%$ were project engineers. On the other hand, 17 respondents representing $15 \%$ of the stakeholders were site engineers whilst 23 respondents representing $21 \%$ were site supervisors. 
Table 1 - Position in organisation

\begin{tabular}{|l|c|c|}
\hline \multicolumn{1}{|c|}{ Position } & Frequency & Percentage \\
\hline Project Manager & 51 & 46 \\
\hline Project Engineer & 20 & 18 \\
\hline Site Engineer & 17 & 15 \\
\hline Site Supervisor & 23 & 21 \\
\hline Total & 111 & 100 \\
\hline
\end{tabular}

However, Table 2 below describes the working experience of the stakeholders or respondents, 19 respondents representing $17 \%$ have between 1-3 years of working experience whilst 25 respondents representing $23 \%$ have between 4-6 years working experience. On the other hand, 25 respondents representing $23 \%$ of the stakeholders were having between 7-9 years of working experience whilst 42 respondents representing $37 \%$ have 10 years and above working experience in the construction industry.

Table 2 - Working experience

\begin{tabular}{|l|c|c|}
\hline \multicolumn{1}{|c|}{ Parameters } & Frequency & Percentage \\
\hline $1-3$ years & 19 & 17 \\
\hline 4-6 years & 25 & 23 \\
\hline 7-9 years & 25 & 23 \\
\hline 10 years and above & 42 & 37 \\
\hline Total & 111 & 100 \\
\hline
\end{tabular}

On the other hand, Table 3 indicates the role of the respondents in the various organizations. Based on the data analysis, 10 respondents representing $9 \%$ indicates planning programme of works for construction projects as their specific role in their organisation whilst 14 respondents representing $13 \%$ states that coordinating financial aspects of construction projects as their role in their organization.

Table 3 - Role in organisation

\begin{tabular}{|l|c|c|}
\hline \multicolumn{1}{|c|}{ Parameters } & Frequency & Percentage \\
\hline $\begin{array}{l}\text { Planning programme of } \\
\text { works }\end{array}$ & 10 & 9 \\
\hline $\begin{array}{l}\text { Coordinating financial } \\
\text { aspects }\end{array}$ & 14 & 13 \\
\hline Monitoring subcontractors & 5 & 5 \\
\hline $\begin{array}{l}\text { Daily operations of field } \\
\text { work }\end{array}$ & 12 & 11 \\
\hline Technical adviser & 23 & 21 \\
\hline $\begin{array}{l}\text { Supervision of } \\
\text { construction projects }\end{array}$ & 47 & 41 \\
\hline Total & 111 & 100 \\
\hline
\end{tabular}

Similarly, 5 respondents representing $5 \%$ of the stakeholders indicate that their role is to monitor sub-contractors and ensure project guidelines are maintained. Interestingly, 12 respondents representing $11 \%$ indicate their role as daily operations of field work activities and organization of subcontractors, regular project status reports, assist in project controls such as; budgeting, scheduling and planning of construction projects, while 23 respondents representing $21 \%$ play the role of a technical adviser by ensuring constructions are in accordance with drawings and specifications, levelling and marking out site and regular technical reports on site. Interestingly, 47 respondents representing $41 \%$ indicates that their role is to supervise construction projects, manage and monitor work activities on site.

Causes of low-skilled workers' performance in construction projects in Nigeria. The purpose of this section of the research focuses on the mean ranking analysed on the objective that is the 'causes of low-skilled workers' performance in construction projects in Nigeria'. The data analysed from the survey conducted was evaluated to determine its significance using the average mean index scale adopted by A. Abdullah [1] as shown in Table 4.

Table 4 - Average mean index scale

\begin{tabular}{|c|l|}
\hline Average index & \multicolumn{1}{c|}{ Range } \\
\hline $1.00 \leq$ Average Index $<1.50$ & Not Significant \\
\hline $1.50 \leq$ Average Index $<2.50$ & Slightly Significant \\
\hline $2.50 \leq$ Average Index $<3.50$ & Moderately Significant \\
\hline $3.50 \leq$ Average Index $<4.50$ & Most Significant \\
\hline $4.50 \leq$ Average Index $<5.00$ & Extremely Significant \\
\hline
\end{tabular}

Table 4 demonstrates the average mean index scale based on the five categories of ranges showing that, $1.00 \leq$ Average Index $<1.50$ is not significant, $1.50 \leq$ Average Index $<2.50$ is slightly significant while $2.50 \leq$ Average Index $<3.50$ indicating moderately significant. However, average mean index ranges of $3.50 \leq$ Average Index $<$ 4.50 is showing most significant and lastly, ranges of $4.50 \leq$ Average Index $<5.00$ indicates the mean is extremely significant. Therefore, the mean ranking for the variables under the low causes of skilled workers' performance in construct projects was determine using the average mean index scale. Table 5 illustrates the results of the mean ranking obtained from the causes of low-skilled workers' performance in construc- 
tion projects in Nigeria. The data were analysed using mean ranking, where the result of the findings provide an indication of the causes of low- skilled workers' performance in construction projects in Nigeria.

Table 5 - Ranking for causes of low-skilled workers' performance in construction projects in Nigeria

\begin{tabular}{|l|l|c|c|}
\hline No & \multicolumn{1}{|c|}{ Variables } & Mean & Ranking \\
\hline 1 & Low wages of skilled workers & 3.78 & 1 \\
\hline 2 & Lack of sufficient skill acquisition centres for skilled workers & 3.74 & 2 \\
\hline 3 & Lack of incentive scheme programmes for skilled workers & 3.70 & 3 \\
\hline 4 & Vulnerability to safety and health care services on site & 3.69 & 4 \\
\hline 5 & Lack of standard salary scales for skilled workers & 3.68 & 5 \\
\hline 6 & Delay in supply of materials and equipment to site & 3.67 & 6 \\
\hline 7 & Ineffective vocational training programmes for skilled workers & 3.64 & 7 \\
\hline 8 & Outdated machines for operation on site & 3.62 & 8 \\
\hline 9 & Delay in payment of skilled workers' wages & 3.56 & 9 \\
\hline 10 & Lack of free medical facilities for skilled workers & 3.52 & 10 \\
\hline 11 & Plants malfunction and maintenance on site & 3.49 & 11 \\
\hline 12 & Shortage of plants and equipment on site & 3.48 & 12 \\
\hline 13 & Lack of free transportations for skilled workers & 3.46 & 13 \\
\hline 14 & Change of orders of project execution & 3.45 & 14 \\
\hline 15 & Excessive rework by skilled workers due to construction errors & 3.41 & 15 \\
\hline 16 & Conflicts among skilled workers on site & 3.34 & 16 \\
\hline 17 & Lack of free residential accommodations for skilled workers & 3.27 & 17 \\
\hline 18 & Unfavourable weather conditions & 3.26 & 18 \\
\hline 19 & Lack of free food vouchers for skilled workers & 3.19 & 19 \\
\hline 20 & Lack of issuance of training certificates to qualified skilled workers on completion & 3.10 & 20 \\
\hline 21 & Of training programmes & 3.05 & 21 \\
\hline 22 & Lack of gifts during festive periods for skilled workers & 3.04 & 22 \\
\hline 23 & Lack of opportunity to observe public holidays for skilled workers & 2.81 & 23 \\
\hline
\end{tabular}

Based on Table 5, the results were arranged from the highest mean to the lowest. Twenty-three variables satisfied by project managers, project engineers, site engineers and site supervisors. Based on their responses, low wages of skilled workers are the most significant factors that causes low-skilled workers' performance in construction projects in Nigeria was ranked 1st. From the ranking, it has a mean value of 3.78, which is the highest compare to the remaining factors within the group. Lack of sufficient skill acquisition centres for skilled workers ranked 2 nd with a mean value of 3.74 , which is the next factors among the causes of low-skilled workers' performance in construction projects in Nigeria. Ranked 3rd was lack of incentive scheme programmes for skilled workers, which has a mean value 3.70 among the causes of low-skilled workers' performance in construction projects in $\mathrm{Ni}$ geria. Furthermore, vulnerability to safety and health care services on site has a mean value of
3.69 among the causes of low-skilled workers' performance in construction projects in Nigeria and was ranked 4 th, and lack of standard salary scale for skilled workers ranked 5th with a mean value of 3.68 in the research findings on the causes of low-skilled workers' performance in construction projects in Nigeria. Delay in supply of materials and equipment to site with a mean value of 3.67 among the causes of low-skilled workers' performance in construction projects in Nigeria and was ranked 6th, while ineffective vocational training programmes for skilled workers having mean value of 3.64 among the causes of low of skilled workers' performance in construction projects in Nigeria ranked 7th. In addition, outdated machines for operation on site, has a mean value of 3.62 as part of the factors causes low-skilled workers' performance in construction projects in Nigeria and was ranked 8th. Delay in payment of skilled workers' wages with a mean value of 3.56 as factor causes low-skilled 
workers' performance in construction projects in Nigeria having ranked 9th, and in the group, lack of free medical facilities for skilled workers has a mean value of 3.52 among the factors causes lowskilled workers' performance in construction projects in Nigeria was ranked 10th.

Plants malfunction and maintenance on site, shortage of plants and equipment on site, lack of free transportations for skilled workers, change of orders of project execution and excessive rework by skilled workers due to design error were having a mean values of 3.49, 3.48, 3.46, 3.45 and 3.41 respectively. On the other hand, conflicts among skilled workers on site, lack of residential accommodation for skilled workers, unfavourable weather conditions, lack of free food vouchers for skilled workers and lack of issuance of training certificates to qualified skilled workers on completion of training programmes were having a mean values of $3.34,3.27,3.26$, 3.19 and 3.10 respectively. Lastly, overcrowding of skilled workers during project execution, lack of gifts for skilled during festive periods and lack of opportunity to observe public holidays for skilled workers were having a mean values of $3.05,3.04$ and 2.81 respectively.

\section{Conclusions}

It has been clearly stressed that the importance of labour management in the construction industry cannot be over emphasized when it comes to the productivity of workers and project performance. The causes of low-skilled workers' performance in construction projects in Nigeria' as the major objective of this paper was achieved through survey using well-structured questionnaire form to selected positions in the Nigerian construction industry such as; project manager, project engineer, site engineer and site supervisor. However, the findings revealed that, five most significant causes of low-skilled workers' performance in the Nigerian construction indus- try. These are; low wages, lack of sufficient skill acquisition centres, lack of incentive schemes programmes, vulnerability to safety and health care services and lack of standard salary scales for skilled workers. Therefore, there is the need to curtail the listed causes of low-skilled workers' performance in order to improve by various motivational factors so as to achieve successful construction project delivery in the Nigerian Construction Industry.

\section{Recommendations}

However, in light of the preceding conclusions, the following recommendations are offered as possible means of enhancing skilled workers' performance in Nigerian construction industry, particularly in Maiduguri, Borno State, as it will go a long way in reducing the poor quality of building stock being constructed in the area. Contractors and other stakeholders in the Nigerian construction should take it as a responsibility to train skilled workers through a well-established skill acquisition centres. Hence, there is the need to organize sensitization programmes and workshops so as to enlighten skilled workers of the importance of improving their performance toward an effective execution of projects in the $\mathrm{Ni}$ gerian construction industry.

\section{Potential Benefits of the Research}

The construction industry is the major beneficiary of this research findings. The contractors and other key players in the industry are going to benefit especially if the contractors avoid or minimise the causes of low-skilled workers' performance in construction projects. Motivation of skilled workers through various means as previously mentioned if strictly abided by contractors will improve skilled workers' performance and productivity towards successful project delivery.

\section{References}

1. Abdullah, A., Mohandes, S., Hamid, A., \& Singh, B. (2016). The Practices of Corporate Social Responsibility among Construction Companies in Malaysia. Research Journal of Applied Sciences, Engineering and Technology, 2(7), 742-755. doi: 10.19026/rjaset.12.2750

2. Abdulsalam, D., Faki, A. I. , \& Dardau, A. A. (2012). Impact Assessment of Incentive Schemes for the Sustainable Development of Nigerian Construction Industry. Journal of Civil Engineering and Architecture, 6(9), 1194-1201. 
3. Adamu, K. J., Dzasu, W. E., Haruna, A., \& Balla, S. K. (2011). Labour productivity constraints in the Nigerian construction industry. Continental Journal of Environmental Design and Management, 1(2), 9-13.

4. Adedokun, O. A., Ibironke, O. T., \& Olanipekun, A. O. (2013). Vulnerability of motivation schemes in enhancing site workers productivity for construction industry's sustainability in Nigeria. International Journal of Sustainable Construction Engineering and Technology, 4(1), 21-30.

5. Adewale, P. O., Siyanbola, A. B., \& Siyanbola, S. O. (2014). Building craftsmanship skill development and Nigeria's vision 20: 2020: Imperatives and daunting challenges. International Journal of Vocational and Technical Education, 6(4), 36-42.

6. Aibinu, A. A. , \& Jagboro, G. O. (2002). The effects of construction delays on project delivery in Nigerian construction industry. International Journal of Project Management, 20(8), 593-559. doi: 10.1016/S0263-7863(02)00028-5

7. Aina, 0. 0., \& Adesanya, D. A. (2015). Factors affecting performance of incentive schemes in the construction industry in Nigeria. Civil and Environmental Research, 8(7), 81-89.

8. Aiyetan, A. O., \& Olotuah, A. O. (2006). Impact of motivation on workers' productivity in the Nigerian construction industry. In D. Boyd (Ed.), Proceedings 22nd Annual ARCOM Conference, 4-6 September 2006, Birmingham (UK), Association of Researchers in Construction Management (pp. 239-248). Retrieved from http://www.arcom.ac.uk/-docs/proceedings/ar2006-02390248_Aiyetan_and_Olotuah.pdf

9. Akinsiku, O. E., \& Akinsulire, A. (2012). Stakeholders' perception of the causes and effects of construction delays on project delivery. Journal of Construction Engineering and Project Management, 2(4), 25-31. doi: 10.6106/jcepm.2012.2.4.025

10. Alinaitwe, H., Mwakali, J., \& Hansson, B. (2006). Factors Affecting Productivity of Building Craftsmen A Case of Uganda. In Proceedings from the International Conference on Advances in Engineering and Technology (pp. 277-284). doi: 10.1016/b978-008045312-5/50031-5

11. Almutairi, Y., Arif, M., \& Khalfan, M. (2016). Moving towards managing offsite construction techniques in the Kingdom of Saudi Arabia: a review. Middle East Journal of Management, 3(2), 164-178. doi: 10.1504/MEJM.2016.078533

12. Ameh, O. J. , \& Shokumbi, B. B. (2013). Effectiveness of non-financial motivational scheme on construction workers output in Nigeria. Ethiopian Journal of Environmental Studies and Management, 6(3), 263-72. doi: 10.4314/ejesm.v6i3.6

13. Aniekwu, N., \& Ozochi, C. (2010). Restructuring education, training and human-resource development in the Nigerian construction industry. International Journal of Science and Technology Education Research, 1(5), 92-98.

14. Arshad, M. N., \& Ab Malik, Z. (2015). Quality of human capital and labour productivity: A Case of Malaysia. International Journal of Economics, Management and Accounting, 23(1), 37-55.

15. Attar, A. A., Gupta, A. K., \& Desai, D. B. (2012). A study of various factors affecting labour productivity and methods to improve it. IOSR Journal of Mechanical and Civil Engineering, 1(3), 11-14.

16. Bernardin, H. J., Kane, J. S., \& Wiatrowski, M. (1995). Performance appraisal. In N. Brewer \& C. Wilson (Eds.), Psychology and Policing (pp. 257-289). Hillsdale: Lawrence Erlbaum Associates.

17. Bheemaiah, K., \& Smith, M. J. (2015, June 2). Inequality, Technology and Job Polarization of the Youth Labour Market in Europe. doi: 10.2139/ssrn.2615605

18. Bilau, A. A., Ajagbe, A. M., Kigbu, H. H., \& Sholanke, A. B. (2015). Review of shortage of skilled craftsmen in small and medium construction firms in Nigeria. Journal of Environment and Earth Science, 5(15), 5-12. 
19. Brockman, J. (2012, December). The Cost of Interpersonal Conflicts in Construction. Retrieved from http://www.cpwr.com/sites/default/files/publications/brockmancostofconflict.pdf

20. Chandra, H. P. (2015). Initial investigation for potential motivators to achieve sustainable construction safety and health. Procedia Engineering, 125, 103-108. doi: 10.1016/j.proeng.2015.11.016

21. Chandrasekar, K. (2011). Workplace environment and its impact on organisational performance in public sector organisations. International Journal of Enterprise Computing and Business Systems, 1(1), 1-19.

22. Cox, R. F., Issa, R. R., \& Frey, A. (2006). Proposed Subcontractor-Based Employee Motivational Model. Journal of Construction Engineering and Management, 132(2), 152-163. doi: 10.1061/(ASCE)0733-9364(2006)132:2(152)

23. Danso, H. (2014). Poor Workmanship and Lack of Plant/Equipment Problems in the Construction Industry in Kumasi, Ghana. International Journal of Management Research, 2(3), 60-70.

24. Davenport, T. H. (2008). Thinking for a living: how to get better performances and results from knowledge workers. Boston: Harvard Business Press.

25. Doloi, H., Sawhney, A., Iyer, K. C., \& Rentala, S. (2012). Analysing factors affecting delays in Indian construction projects. International Journal of Project Management, 30(4), 479-489. doi: 10.1016/j.ijproman.2011.10.004

26. Enshassi, A., Mohamed, S., Mustafa, Z. A., \& Mayer, P. E. (2007). Factors affecting labour productivity in building projects in the Gaza Strip. Journal of Civil Engineering and Management, 13(4), 245254.

27. Funso, A., Sammy, L., \& Gerryshom, M. (2016). Application of Motivation in Nigeria Construction Industry: Factor Analysis Approach. International Journal of Economics and Finance, 8(5), 271276. doi: 10.5539/ijef.v8n5p271

28. Garcés-Mascareñas, B. (2015). Revisiting bordering practices: Irregular migration, borders, and citizenship in Malaysia. International Political Sociology, 9(2), 128-142. doi: 10.1111/ips.12087

29. Ghoddousi, P., Poorafshar, O., Chileshe, N., \& Hosseini, M. R. (2015). Labour productivity in Iranian construction projects: Perceptions of chief executive officers. International Journal of Productivity and Performance Management, 64(6), 811-830. doi: 10.1108/IJPPM-10-2013-0169

30. Griggs, T. L., Eby, L. T., Maupin, C. K., Conley, K. M., Williamson, R. L., Griek, O. H., \& Clauson, M. G. (2016). Who Are These Workers, Anyway? Industrial and Organizational Psychology, 9(1), 114121. doi: 10.1017/iop.2015.123

31. Hershcovis, M. S., Barling, J. (2010). Towards a multi-foci approach to workplace aggression: A meta-analytic review of outcomes from different perpetrators. Journal of Organizational Behavior, 31(1), 24-44. doi: 10.1002/job.621

32. Hickson, B. G., \& Ellis, L. A. (2014). Factors affecting construction labour productivity in Trinidad and Tobago. The Journal of the Association of Professional Engineers of Trinidad and Tobago, 42(1), 4-11.

33. Hughes, P., \& Ferrett, E. (2016). Introduction to Health and Safety in Construction: for the NEBOSH National Certificate in Construction Health and Safety (5th ed.). Abingdon; New York: Routledge.

34. Husseini, A. A. (1992). The importance of manpower training and management to the construction industry. In Proceedings of National Seminar on Effective Contract Management in the Construction Industry, Ikeja, August 22-23, 1991 (pp. 119-131). Lagos: Nigerian Institute of Building.

35. Hyder, M. B. (2016). Vulnerability, sustainable livelihoods and workers' rights: a case study of construction workers in Dhaka, Bangladesh (Master's thesis). Retrieved from https://brage.bibsys.no/xmlui/handle/11250/2398839 
36. Ibrahim, M. (2013). Contractors perspective toward factors affecting labour productivity in building construction. Engineering, Construction and Architectural Management, 20(5), 446-60. doi: 10.1108/ECAM-08-2011-0074

37. Ikediashi, D. I., Ogunlana, S. O., Awodele, O. A., \& Okwuashi, O. (2012). An evaluation of personnel training policies of construction companies in Nigeria. Journal of Human Ecology, 40(3), 229238.

38. Jarkas, A. M., \& Radosavljevic, M. (2013). Motivational factors impacting the productivity of construction master craftsmen in Kuwait. Journal of Management in Engineering, 29(4), 446-454. doi: 10.1061/(asce)me.1943-5479.0000160

39. Kamar, K. A., Azman, M. N. , \& Nawi, M. N. (2014). IBS Survey 2010: Drivers, Barriers and the Critical Success Factors in Adopting Industrialised Building System (IBS) Construction by G7 Contractors in Malaysia. Journal of Engineering Science \& Technology, 9(5), 490-501.

40. Kaming, P. (1997). Factors influencing craftsmen's productivity in Indonesia. International Journal of Project Management, 15(1), 21-30. doi: 10.1016/S0263-7863(96)00019-1

41. Kazaz, A., Manisali, E., \& Ulubeyli, S. (2008). Effect of basic motivational factors on construction workforce productivity in Turkey. Journal of Civil Engineering and Management, 14(2), 95-106. doi: 10.3846/1392-3730.2008.14.4

42. Kuroshi, P. A., Lawal, M. (2014). Study of internal factors affecting labour productivity in medium sized construction firms in Nigeria. International Journal of Education and Research, 2(12), 8392.

43. Liepmann, K. (1960). Apprenticeship: An Enquiry into Its Adequacy under Modern Conditions. London: Routledge.

44. Ling, Y. Y., \& Tan, F. (2015). Selection of site supervisors to optimize construction project outcomes. Structural Survey, 33(4/5), 407-422. doi: 10.1108/SS-08-2015-0041

45. Modular Building Institute. (2010). Improving efficiency and productivity with modular construction. Retrieved from

http://www.modular.org/marketing/documents/Whitepaper_ImprovingConstructionEfficiency .pdf

46. Moselhi, O., Assem, I., \& El-Rayes, K. (2005). Change orders impact on labour productivity. Journal of Construction Engineering and Management, 131(3), 354-359. doi: 10.1061/(ASCE)07339364(2005)131:3(354)

47. Naoum, S. G. (2016). Factors influencing labor productivity on construction sites: A state-of-the-art literature review and a survey. International Journal of Productivity and Performance Management, 65(3), 401-421. doi: 10.1108/IJPPM-03-2015-0045

48. Odesola, I. A, Otali, M., \& Ikediashi, D. I. (2013). Effects of project-related factors on construction labour productivity in Bayelsa State of Nigeria. Ethiopian Journal of Environmental Studies and Management, 6(2), 817-819. doi: 10.4314/ejesm.v6i6.12S

49. Odesola, I. A. (2015). Assessment of Management-Related Factors Affecting Construction Labour Productivity in Cross River State of Nigeria. Covenant Journal of Research in the Built Environment, 3(2), 13-29.

50. Odia, L. O, \& Omofonmwan, S. I. (2007). Educational system in Nigeria problems and prospects. Journal of Social Sciences, 14(1), 81-86.

51. Offei-Nyako, K., Osei-Tutu, E., Fugar, F. D., \& Adinyira, E. (2013). Skilled artisanal availability in the Ghanaian construction industry. Covenant Journal of Research in the Built Environment, 1(1), 1-9.

52. Ogochukwu, O. C. (2014). Evaluating the Impact of Construction Crafts'Skills Acquisition and Critical Knowledge Development on Project Performance in Nigeria (Doctoral thesis). Retrieved from http://my.unizik.edu.ng/postgraduate/dload2.php?downloads=976 
53. Ogwu, B. (2015). Nigeria: Technical, Vocational Education and Training. In E. Takyi-Amoako (Ed.), Education in West Africa (Chapter 23). London: Bloomsbury Publishing.

54. Okafor, N. (2010). Funding the Rehabilitation of Universities. The Alumnus Special Millennium Education Journal, 1, 55-56.

55. Olateju, B. (1992). Enhancing the contract management capabilities of the indigenous contractors. In Proceedings of National Seminar on Effective Contract Management in the Construction Industry, Ikeja, August 22-23, 1991 (pp. 132-143). Lagos: Nigerian Institute of Building.

56. Olatunji, O. A, Aje, O. I, Odugboye, F. (2007). Evaluating health and safety performance of Nigerian construction site. Retrieved from https://www.irbnet.de/daten/iconda/CIB4786.pdf

57. Olubodun, O. (1985). Low productivity of the Nigerian construction workers. In Report No. Unpublished Seminar Paper, Building Department, OAU, Ile-Ife.

58. Oni, C. S. (2007). Globalization and Its Implication for Vocational Education in Nigeria. Essays in Education, 21(1), 30.

59. Oseghale, B. O, Abiola-Falemu, J. O., \& Oseghale, G. E. (2015). An Evaluation of Skilled Labour shortage in selected construction firms in Edo state, Nigeria. American Journal of Engineering Research, 1(4), 156-167.

60. Parida, R., Sarkar, S., \& Ray, P. (2016). Selection of Alternate Work Systems to Improve Occupational Health of Indian Construction Workers: A Design of Experiment-Based Approach. In P. Mandal \& J. Vong (Eds.), Smart Technologies for Smart Nations (pp. 155-173). Singapore: Springer Singapore. doi: 10.1007/978-981-287-585-3

61. Rojas, V. M., \& Kleiner, B. H. (2000). The Art and Science of Effective Stress Management. Management Research News, 23(7/8), 103-106. doi: 10.1108/01409170010782280

62. Salisu, J. B., Chinyio, E., \& Suresh, S. (2015). The impact of compensation on the job satisfaction of public sector construction workers of jigawa state of Nigeria. The Business \& Management Review, 6(4), 282-296.

63. Schwarzkopf, W. (2004). Calculating lost labour productivity in construction claims (2nd ed.). Maryland: Frederick Aspen Publisher.

64. Sheebe, J. (2016). A study on the impact of training programs of Central Board for Workers Education on the quality of work life of the organized, unorganized and rural labour in Kerala. Retrieved from http://www.baselius.ac.in/wp-content/uploads/2017/06/sheeba-1.pdf

65. Sherekar. V., \& Tatikonda, M. (2016). Impact of Factor Affecting on Labour Productivity in Construction Projects by AHP Method. International Journal of Engineering Science and Computing, 6(6), 6771-6775.

66. Sinha, P. (2015). Towards higher maintenance effectiveness: Integrating maintenance management with reliability engineering. International Journal of Quality \& Reliability Management, 32(7), 754-762. doi: 10.1108/IJQRM-03-2013-0039

67. Sweet, S., \& Meiksins, P. (2017). Changing contours of work: Jobs and opportunities in the new economy (3rd ed.). Los Angeles: SAGE.

68. Uchitelle, L. (2009, June 23). Despite Recession, High Demand for Skilled Labor. The New York Times. Retrieved from http://www.nytimes.com/2009/06/24/business/24jobs.html

69. Venugopal, V., Chinnadurai, J., Vennila, V., Ajit, R., Lucas, R., \& Kjellstrom, T. (2016). The Social Implications of Occupational Heat Stress on Migrant Workers Engaged in Public Construction: A Case Study from Southern India. The International Journal of the Constructed Environment, 7(2), 25-36. doi: 10.18848/2154-8587/CGP/v07i02/25-36

70. Wong, J. M., Ng, S. T, \& Chan, A. P. (2010). Strategic planning for the sustainable development of the construction industry in Hong Kong. Habitat International, 34(2), 256-263. doi:

10.1016/j.habitatint.2009.10.002 
71. Yerramreddy, V. A. (2014). Schedule Quality: Delay Analysis Perspective (Doctoral dissertation). Retrieved from https://repository.tudelft.nl/islandora/object/uuid\%3Afd3c938d-2207-41c6b976-0cb33e441a1e

72. Zhang, L, \& Huo, X. (2015). The impact of interpersonal conflict on construction project performance: A moderated mediation study from China. International Journal of Conflict Management, 26(4), 479-498. doi: 10.1108/IJCMA-09-2014-0072

73. Zou, P. X., Zhang, G., \& Wang, J. (2007). Understanding the key risks in construction projects in China. International Journal of Project Management, 25(6), 601-614. doi:

10.1016/j.ijproman.2007.03.001 